\title{
Analysis of Share Buyback Announcements on Stock Price Returns: A Study of BSE Listed Stocks
}

\author{
Vaddula V. Krishna Reddy \\ Department of Accounting and Finance, Amity Global Business School (AGBS) -Hyderabad, \\ Telangana [Amity University (Noida) Uttar Pradesh], India.
}

Type of Work: Peer Reviewed.

DOl: http://dx.doi.org/10.21013/jmss.v16.n3.p4

\section{How to cite this paper:}

Reddy, V.V.K. (2020). Analysis of Share Buyback Announcements on Stock Price Returns: A Study of BSE Listed Stocks. IRA-International Journal of Management \& Social Sciences (ISSN 24552267), 16(3), 98-104. doi:http://dx.doi.org/10.21013/jmss.v16.n3.p4

(C) Institute of Research Advances.

\section{(cc) EY-NC}

This work is licensed under a Creative Commons Attribution-NonCommercial 4.0 International License subject to a proper citation to the publication source of the work.

Disclaimer: The scholarly papers as reviewed and published by the Institute of Research Advances (IRA) are the views and opinions of their respective authors and are not the views or opinions of the IRA. The IRA disclaims of any harm or loss caused due to the published content to any party.

Institute of Research Advances is an institutional publisher member of Publishers International Linking Association Inc. (PILA-CrossRef), USA. The institute is an institutional signatory to the Budapest Open Access Initiative, Hungary advocating the open-access of scientific and scholarly knowledge. The Institute is a registered content provider under Open Access Initiative Protocol for Metadata Harvesting (OAI-PMH).

The journal is indexed \& included in WorldCat Discovery Service (USA), CrossRef Metadata Search (USA), WorldCat (USA), OCLC (USA), Open J-Gate (India), EZB (Germany) Scilit (Switzerland), Airiti (China), Bielefeld Academic Search Engine (BASE) of Bielefeld University, Germany, PKP Index of Simon Fraser University, Canada. 


\section{ABSTRACT}

Buyback is a procedure that enables a company to repurchase its shares from its existing shareholders, usually at a price near to or higher than the prevailing market price. The present study is based on secondary data and the event window period of 21 days (10 days before the announcement and 10 days after the announcement) are taken to measure its impact. Based on data availability 24 sample companies cover public sector undertakings and information technology companies selected for the study. The cumulative abnormal return for the entire 21 day period is $1.31 \%$. T-statistic 2.066 with p-value $(0.069>0.05)$ at a $5 \%$ level of significance indicates that accept the null hypothesis and conclude that there is a significant difference of ARR between pre and post buyback announcement of sample companies.

Keywords: Share Buyback, Market Model, BSE SENSEX, Abnormal Return, Cumulative Abnormal Return

\section{Introduction}

Buyback is a procedure that enables a company to repurchase its shares from its existing shareholders, usually at a price near to or higher than the prevailing market price. This becomes a leading payout mode over dividends(Grullon \& Michaely, Dividends, share repurchases, and the substitution hypothesis, 2002; Skinner, 2008; Dittmar, 2000). It is the option available to shareholders to exit from the company. It is governed by section 68 of the Companies Act, 2013 whether the company is listed or unlisted, both can opt for the process of buy-back of shares. It is relevant to note that the company can buy-back or repurchase equity as well as preference shares when it is fully paid up. Some of the motives for buyback are to improve earnings per share, to use ideal cash, to improve return on capital, return on net-worth, and to return surplus cash to the shareholders(Stephens \& Weisbach, 1998).

Buyback of shares can be done either through the open market or through the tender offer route. (Dann, 1981; Vermaelen T. , 1981; Asquith \& Mullins, 1986) have found significant positive abnormal returns correlate with the announcement of each of the two types of repurchase announcements. Under the open market method, the company can buy back its shares through the stock exchange or book-building process. Here the promoters and shareholders of the company are allowed to offer their shares for the buyback. In the tender offer share buyback method, the company fixes the number of shares and buyback prices from the market during a defined period. The company also has the option to lower the number of shares and price for buying back according to the situations. There is one more method known as Odd-lot buyback but the procedure for the tender offer and oddlot buyback is the same. The present paper is an attempt to understand the effect of the announcement of buyback on the share prices under the tender offer method at the Bombay Stock Exchange (BSE), India.

\section{Review of Literature}

In the view of increasing demand for share buybacks, there is plenty of literature on the subject, a brief review of the same is presented below which are related to the present study. (Asquith \& Mullins, 1986) mentioned that the signaling role of dividends and stock repurchases is different but the objective is the same behind both i.e., to pay excess cash to the shareholders. The companies offer dividend advice that the firm has a bright future and when it goes for share buyback it advises that the share is undervalued. (Gupta A. , 2006) revealed that CAR of $12.89 \%$ is significant for 46 buybacks of 61-day event period and the average abnormal return on the day of announcement is $1.68 \%$, which is significant at a $1 \%$ level. (S Kumar Pradhan R. Kasilingam, 2016) Conclude that the buyback announcement does not have an impact on the share price in the industry-wise analysis but have a partial impact on the share price in a subject to company-wise analysis. The abnormal returns and cumulative abnormal returns of most companies are positive in both the long run and short run. (Nohel \& Tarhan, 1998) investigates tender share buybacks to distinguish between the information signalling and free cash flow hypothesis and determine that the positive investor reaction to buybacks is interpreted by the free cash flow hypothesis.

Recent research has provided evidence that investment horizon affects stock price behaviour around the release of corporate information, such as mergers(Gaspar, Massa, \& Matos, 2005; Chen, Harford, \& Li, 2007), earning announcements (Hotchkiss \& Strickland, 2003), and seasoned equity offerings(Gibson, Safieddine, \& Sonti, 2004). (Mohanty, 2002) attempted to analyze 12 buybacks and found an average abnormal return of around $0.56 \%$ on the date of announcement and an overall CAR of $11.26 \%$ for a 61-day event period. (Karamjit Kaur Neelam Dhanda, 2016) Found that the buyback of shares gave as a positive signal for investors, but negative for 
post and pre buyback and the results indicate that there is no significant difference between post and pre average abnormal return of buyback. (Sarin, 2013) Reveals that the share price of the company is not always positive after the buyback of shares and he also analyzed the post-buyback effect, noted that share price of more than $90 \%$ of the firms announcing buyback has gone up. (Ikenberry, Lakonishok, \& Vermaelen, 1995) indicated that the average market response shares repurchase was only $3.5 \%$, despite public endorsement made by the company that the shares were undervalued and it was a good investment.

\section{Research Methodology}

This paper is to analyze the announcement impact on share buybacks. The present study is based on secondary data and the event window companies of 21 days (10 days before the announcement and 10 days after the announcement) are taken to measure its impact. The announcement date is noted as 0 and before announcement date and after announcement date is denoted as 0 to -10 and 0 to 10 respectively. The present study uses the market model to measure the stock-price reaction to the initial announcements of stock buybacks. The estimation period covers from -240 day to -11 . The study uses the BSE SENSEX as an intermediary measure of the market portfolio over a one year estimation period. The objective of this research papers is

1. To measure the impact of buyback announcement on average abnormal return of pre and post-event window of 21 days.

2. To attain the above objective, the following hypothesis is framed:

Null Hypothesis (Ho): There is no significant difference in average abnormal return of pre and post announcement for the event window of 21 days

During the study period from 01.04.2016 to 31.03.2020 181companies of different sectors buyback the shares under the tender offer method at the Bombay Stock Exchange (BSE) website. The researcher has observed that many public sector undertakings and information technology companies buyback the shares during the above period. Based on data availability 24 sample companies cover public sector undertakings and information technology companies selected for the study. Statistical tools such as Abnormal Return, Average Abnormal Returns, Cumulative Average Abnormal Returns, t-test, and paired t-test had been used.

Based on the market model the abnormal returns on a particular trading day $\mathrm{t}$ are calculated using the following equation:

$\mathrm{AR}_{\mathrm{i}, \mathrm{t}}=\mathrm{R}_{\mathrm{i}, \mathrm{t}}-\alpha_{\mathrm{i}}-\beta_{\mathrm{i}} \mathrm{R}_{\mathrm{m}, \mathrm{t}}$

where $\mathrm{AR}_{\mathrm{i}, \mathrm{t}}$ is the abnormal return on security $\mathrm{i}$ for day $\mathrm{t}$, and $\mathrm{R}_{\mathrm{m}, \mathrm{t}}$ is the return on market portfolio, $\alpha_{\mathrm{i}}$ and $\beta_{\mathrm{i}}$ are intercept and slope respectively and are predicted using the following equation:

$\mathrm{R}_{\mathrm{i}, \mathrm{t}}=\alpha_{\mathrm{i}}+\beta_{\mathrm{i}} \mathrm{R}_{\mathrm{m}, \mathrm{t}}+\mathrm{e}_{\mathrm{i}, \mathrm{t}}$

for calculating the values of $\mathrm{R}_{\mathrm{m}, \mathrm{t}}$ and $\alpha_{\mathrm{i}}, \beta_{\mathrm{i}}$, the study uses BSE SENSEX as an intermediary measure of market portfolio.

The Average Abnormal return on day $\mathrm{t}$ is calculated as:

$\mathrm{AAR}_{\mathrm{t}}=\frac{\sum_{i=1}^{n} A R_{i, t}}{N}$

where $\mathrm{N}$ is the number of announcements in the sample.

The daily AARs are cumulated over the window period to calculate the Cumulative Abnormal Return as:

$\mathrm{CAR}=\sum_{t=-d}^{d} A A R_{i, t}$

where $-\mathrm{d}$ and $\mathrm{d}$ represent the event window period. 
IRA-International Journal of Management \& Social Sciences

Data Analysis

Table - 1: Results of Market Model

\begin{tabular}{|c|c|c|c|c|c|c|}
\hline S No. & Name of Company & $\begin{array}{c}\text { Announcement } \\
\text { Date }\end{array}$ & Intercept & Slope & $\begin{array}{c}\mathrm{R}- \\
\text { square }\end{array}$ & $\begin{array}{c}\text { Standard } \\
\text { Error }\end{array}$ \\
\hline 1 & Bharti Infratel Limited & $17-06-2016$ & -0.00041 & 0.7183 & 0.0812 & 0.0256485 \\
\hline 2 & Hexaware Technologies Limited & $30-12-2016$ & -0.00049 & 1.073 & 0.2728 & 0.0165755 \\
\hline 3 & Tata Consultancy Services Ltd & 25-04-2017 & -0.00015 & 0.5856 & 0.0944 & 0.0137590 \\
\hline 4 & Engineers India Limited & 23-06-2017 & 0.001528 & 1.1489 & 0.1274 & 0.02117019 \\
\hline 5 & Infosys Limited & $12-10-2017$ & -0.00076 & 0.7886 & 0.1202 & 0.0137763 \\
\hline 6 & Danlaw Technologies India Limited & $15-11-2017$ & 0.00063 & 0.8181 & 0.0197 & 0.0343120 \\
\hline 7 & Bharat Electronics Limited & 08-02-2018 & -0.00018 & 1.1666 & 0.1782 & 0.0138849 \\
\hline 8 & HCL Technologies Limited & 24-08-2018 & 0.000301 & 0.4043 & 0.0292 & 0.0149103 \\
\hline 9 & NLC India Limited & $15-10-2018$ & -0.00144 & 0.4925 & 0.0386 & 0.0162157 \\
\hline 10 & National Aluminium Co & 23-10-2018 & -0.00066 & 1.0186 & 0.0665 & 0.0266812 \\
\hline 11 & Cochin Shipyard Limited & $23-10-2018$ & -0.00163 & 0.4863 & 0.0799 & 0.011537 \\
\hline 12 & NHPC Limited & $22-11-2018$ & -0.00018 & 0.6624 & 0.1019 & 0.0150026 \\
\hline 13 & Indian Oil Corporation Limited & 27-11-2018 & -0.00138 & 1.2178 & 0.1631 & 0.0212641 \\
\hline 14 & Oil India Limited & $27-11-2018$ & $6.86 \mathrm{E}-05$ & 0.2371 & 0.0018 & 0.0420450 \\
\hline 15 & Oil \& Natural Gas Corporation Limited & $27-12-2018$ & -0.00132 & 0.9642 & 0.1659 & 0.0170560 \\
\hline 16 & NMDC Limited & 15-01-2019 & -0.00166 & 1.1345 & 0.2043 & 0.0180857 \\
\hline 17 & R Systems International Limited & 22-01-2019 & 0.000709 & 0.8500 & 0.0535 & 0.028827 \\
\hline 18 & Coal India & 08-02-2019 & -0.00086 & 0.3711 & 0.0405 & 0.0141494 \\
\hline 19 & Tech Mahindra Limited & 28-02-2019 & 0.001257 & 0.6843 & 0.0776 & 0.0186164 \\
\hline 20 & Wipro Ltd & $12-06-2019$ & 0.001374 & 0.4259 & 0.0587 & 0.014300 \\
\hline 21 & Sasken Technologies Limited & 05-07-2019 & -0.00123 & 0.789 & 0.0860 & 0.0218715 \\
\hline 22 & BSE Limited & 23-07-2019 & -0.00103 & 0.3369 & 0.0601 & 0.0114939 \\
\hline 23 & MOIL Limited & 20-11-2019 & -0.00097 & 0.7301 & 0.1621 & 0.0153046 \\
\hline 24 & NIIT TECHNOLOGIES LTD & 20-02-2020 & 0.001365 & 0.4613 & 0.0574 & 0.0168454 \\
\hline
\end{tabular}

Table 1 reveals the results of Market Model. Equation 2 is used to find the intercept and slope. In the sample 16 companies have negative intercept indicates the riskiness of the companies compared to their expected returns. For the remaining 8 companies with positive intercept means the actual returns may not be as positive as expected. The slope is positive for all sample companies which indicates less volatility. $\mathrm{R}$ square shows a positive association among all the sample companies between individual stock return and benchmark index.

Table 2: ARR and CAR for 24 buybacks in 21-day window

\begin{tabular}{|c|c|c|c|c|}
\hline Day & AAR & T-test for AR & CAR & $\begin{array}{c}\text { \% of Companies with } \\
\text { Positive ARR }\end{array}$ \\
\hline-10 & $-0.50 \%$ & -0.2500 & $-0.50 \%$ & 41.67 \\
\hline-9 & $0.55 \%$ & 0.2007 & $0.05 \%$ & 41.67 \\
\hline-8 & $0.90 \%$ & 0.4508 & $0.96 \%$ & 58.33 \\
\hline-7 & $0.46 \%$ & 0.3037 & $1.42 \%$ & 62.50 \\
\hline-6 & $0.37 \%$ & 0.3334 & $1.78 \%$ & 54.17 \\
\hline-5 & $0.30 \%$ & 0.1493 & $2.08 \%$ & 58.33 \\
\hline-4 & $0.15 \%$ & 0.1093 & $2.23 \%$ & 54.17 \\
\hline-3 & $-0.05 \%$ & -0.0572 & $2.18 \%$ & 50.00 \\
\hline-2 & $0.46 \%$ & $2.0184^{*}$ & $2.64 \%$ & 70.83 \\
\hline
\end{tabular}


IRA-International Journal of Management \& Social Sciences

\begin{tabular}{|c|c|c|c|c|}
\hline-1 & $-0.71 \%$ & -0.3663 & $1.93 \%$ & 41.67 \\
\hline 0 & $1.03 \%$ & $2.1437^{*}$ & $2.96 \%$ & 54.17 \\
\hline 1 & $-0.14 \%$ & -0.0694 & $2.82 \%$ & 41.67 \\
\hline 2 & $-0.14 \%$ & 0.0368 & $2.67 \%$ & 45.83 \\
\hline 3 & $-0.52 \%$ & -0.3391 & $2.15 \%$ & 37.50 \\
\hline 4 & $-0.32 \%$ & -0.2133 & $1.83 \%$ & 41.67 \\
\hline 5 & $0.24 \%$ & -0.1214 & $2.07 \%$ & 45.83 \\
\hline 6 & $-0.26 \%$ & -0.0435 & $1.81 \%$ & 58.33 \\
\hline 7 & $0.37 \%$ & 0.2378 & $2.18 \%$ & 62.50 \\
\hline 8 & $-0.57 \%$ & -0.4066 & $1.61 \%$ & 29.17 \\
\hline 9 & $0.23 \%$ & 0.1756 & $1.85 \%$ & 54.17 \\
\hline 10 & $-0.53 \%$ & -0.3025 & $1.31 \%$ & 37.50 \\
\hline
\end{tabular}

*Indicates Significant at $5 \%$ level of significance

Table 2 shows Market Model highlights the average abnormal returns (AAR) and corresponding $\mathrm{T}$ values for each of the 21 days of event window and cumulative abnormal return (CAR). The number of companies with positive ARR for 21 days window period range from $27 \%$ to $70 \%$ of overall sample.ARR on the date of announcement day (0) of 24 buyback is $1.03 \%$ and statistically significant at 5\% level of significance. (Gupta A. , 2006) find an ARR of $1.66 \%$ for 46 buybacks in India while this study finds $1.03 \%$ average return. This finding is similar with many studies and in line with the conclusion of (Ishwar, 2010). It is observed in the above table that AAR is positive in initial days prior to the date of announcement but negative for majority of days after the announcement day indicating that buyback euphoria is only a temporary phenomenon and fails to provide benefits over long time horizon.

The cumulative abnormal return (based on Equation 4) for the entire 21-day period is $1.31 \%$ which compares favourably well with findings of (Hyderabad, 2009). The drop in CAR in post-offer period is associated with negative movement in prices. More than $50 \%$ of sample companies have positive ARR before announcement date, however less than $50 \%$ of sample companies have positive ARR after announcement date. (Vermaelen T., 1981) Found that abnormal returns before announcement can always be interpreted on the basis of information leakages or prior inside trading.

Table 3: Summary of Cumulative Average Abnormal Returns over Different Event Windows

\begin{tabular}{|c|c|c|}
\hline Event Window & $\begin{array}{c}\text { Cumulative Average Abnormal } \\
\text { Return (CAAR) }\end{array}$ & t-Statistic \\
\hline$(-10,0)$ & $1.93 \%$ & 1.381438 \\
\hline$(-5,0)$ & $0.15 \%$ & 0.149596 \\
\hline$(-1,0)$ & $-0.71 \%$ & -1.60779 \\
\hline$(0,+1)$ & $-0.14 \%$ & -0.31657 \\
\hline$(0,+5)$ & $-0.88 \%$ & -0.89259 \\
\hline$(0,+10)$ & $-1.88 \%$ & -1.34636 \\
\hline$(-1,+1)$ & $-1.00 \%$ & -1.31047 \\
\hline$(-2,+2)$ & $-0.69 \%$ & -0.69514 \\
\hline$(-3,+3)$ & $-1.26 \%$ & -1.07499 \\
\hline$(-5,+5)$ & $-0.89 \%$ & -0.60508 \\
\hline$(-10,+10)$ & $-0.10 \%$ & -0.05117 \\
\hline
\end{tabular}

Source: Excel output

Table 3 depicts summary of cumulative abnormal returns of eleven different event windows. First six events ($10,0),(-5,0),(-1,0),(0,+1),(0,+5)$, and $(0,+10)$ indicates cumulative average abnormal return for 10 days, 5 days and 1 day prior and post announcement date respectively. T-statistic values shows that CAAR is not statistically significant at $5 \%$ or $1 \%$ level of significance. The average CAR over the $(-1,+1),(-2,+2),(-3,+3)$, $(-5,+5)$, and $(-10,+10)$ windows is $-1.00 \%,-0.69 \%,-1.26 \%,-0.89 \%$, and $-0.10 \%$ respectively. 
IRA-International Journal of Management \& Social Sciences

Table 4: T Paired Sample Test for 21 Days Window Period

\begin{tabular}{|c|c|c|c|c|c|}
\hline Variables & $\begin{array}{c}\text { Mean } \\
\text { Difference }\end{array}$ & Standard Deviation & Df & t-value & $\begin{array}{c}\text { Sig( } 2 \text { tailed } \\
\text { test })\end{array}$ \\
\hline $\begin{array}{c}\text { AAR } \\
\text { (21 Days Event Window) }\end{array}$ & 0.3572 & 0.54694 & 9 & 2.066 & 0.069 \\
\hline $\begin{array}{c}\text { CAAR } \\
\text { (21 Days Event Window) }\end{array}$ & -.24282 & 0.01381 & 9 & -55.580 & 0.000 \\
\hline
\end{tabular}

Table 4 indicates AAR and CAAR between pre and post announcements of share buyback of select companies in this study. T-statistic 2.066 with p-value $(0.069>0.05)$ at a $5 \%$ level of significance indicates that accept the null hypothesis and conclude that there is a significant difference of ARR between pre and post buyback announcement of sample companies. However, t-statistic of CAAR -55.580 with p-value $(0.000<0.01)$ at a $1 \%$ level of significance shows that reject the null hypothesis and concludes that there is no significant difference in CAAR between pre and post buyback announcement of sample companies. The mean difference between AAR and CAAR is 0.35727 and -0.24282 for 21 days window period respectively.

\section{Findings and Conclusions}

The objective of this research paper is to measure the impact of buyback announcement on average abnormal return of pre and post-event window of 21 days. The study is based on 24 sample companies over the period of 4 years. The market model methodology was adopted to compute abnormal returns. In the sample 16 companies have negative intercept indicates the riskiness of the companies compared to their expected returns. For the remaining 8 companies with positive intercept means the actual returns may not be as positive as expected.

The ARR on the date of announcement day (0) of 24 buyback is $1.03 \%$, and which is statistically significant at $5 \%$ level of significance and the cumulative abnormal return for the entire 21 -day period is $1.31 \%$. T-statistic 2.066 with p-value $(0.069>0.05)$ at a $5 \%$ level of significance indicates that accept the null hypothesis and conclude that there is a significant difference of ARR between pre and post buyback announcement of sample companies.

\section{References}

[1]. Asquith, P., \& Mullins, D. W. (1986). Signalling with dividends, stocks repurchases, and equity issues (Vol. 15). Blackwell Publishing.

[2]. Chen, X., Harford, J., \& Li, K. (2007). Monitoring: Which institutions matter? Journal of Financial Economics, 86(2), 279-305.

[3]. Dann, L. Y. (1981). Common stock repurchases: An analysis of returns to bondholders and stockholders. Journal of Financial Economics, 9(2), 113-138.

[4]. Dittmar, A. K. (2000). Why do firms repurchases stock? The Journal of Business, 73(3), 331-355.

[5]. Fernandes, K. (2019). Top 20 Indian companies for CSR in 2019. Business Ethics \& Philanthropy, The CSR Journal.

[6]. Gaspar, J.-M., Massa, M., \& Matos, P. (2005). Shareholder investment horizons and the market for corporate control. Journal of Financial Economics, 76(1), 135-165.

[7]. Gibson, S., Safieddine, A., \& Sonti, R. (2004). Smart investments by smart money:. Journal of Financial Economics, 72, 581-604.

[8]. Grullon, G., \& Ikenberry, D. L. (2000). What do we know about stock repurchases? Journal of Applied Corporate Finance, 13(1), 31-51.

[9]. Grullon, G., \& Michaely, R. (2002). Dividends, share repurchases, and the substitution hypothesis. The Journal of Finance, 57(4), 1649-1684.

[10].Gupta, A. (2006). Share price behaviour anound buyback of India. The ICFAI Journal of Applied Finance, 12(12), 26-40.

[11].Hotchkiss, E. S., \& Strickland, D. (2003). Does Shareholder Composition Matter? Evidence from the Market Reaction to Corporate Earnings Announcements. The Journal of Finance, 58(4), 1469-1498.

[12].Hyderabad, R. (2009). Market Reaction to Multiple Buybacks in India. IMJ, IIM Indore, 1(2), 18-49.

[13].Ikenberry, D., Lakonishok, J., \& Vermaelen, T. (1995). Market underreaction to open market. Journal of Financial Economics, 39, 181-208.

[14].Ishwar, E. (2010). Stock Price Responses to the Announcement of Buyback of Shares. Indian Journal of Commerce and Management Studies.

[15].Karamjit Kaur Neelam Dhanda. ( 2016). Buy back of shares in India: Impact on stock price returns. EPRA International Journal of Economic and Business Review, 84-96.

[16].Mohanty, P. (2002). Who gains in share buyback. The ICFAI Journal of Applied Finance, 8(6), 19-30. 
[17].Nohel, T., \& Tarhan, V. (1998). Share repurchases and firm performance:: new evidence on the agency costs of free cash flow. Journal of Financial Economics, 49(2), 187-222.

[18].S Kumar Pradhan R. Kasilingam. (2016). Impact of Buyback Announcement on Share Price: A Company and Industry wise Analysis. Int. J. Manag. Bus. Res. 6(1) Winter, 13-21.

[19].Sarin, C. (2013). Motives of Buy-Back: An Empirical Study of Select Indian Companies. International Journal of Commerce, Business and Managment (IJCBM), 386-394.

[20].Skinner, D. J. (2008). The evolving relation between earnings, dividends, and stock repurchases. Journal of Financial Economics, 87(3), 582-609.

[21].Stephens, C. P., \& Weisbach, M. S. (1998). Actual shares reacquisitions in open market repurchase programs. The Journal of Finance, 53, 313-333.

[22].Vermaelen, T. (1981). Common Stock Repurchases and Market Signaling: An Empirical Study. Journal of Financial Economics, 9(2), 139-183. 